\title{
Social and psychological attitudes of students at the different stages of studying
}

\author{
Olga Beluzhenko ${ }^{1}$, Sergey Kuren ${ }^{2}$, Sergey Popov ${ }^{2, *}$, and Nikolai Dontsov ${ }^{2}$ \\ ${ }^{1}$ South-Russian Institute of Management - branch of Russian Academy of National Economy and \\ Public Service under the President of the Russian Federation, 70/54, Pushkinskaya str., 344002, \\ Rostov on Don, Russia \\ ${ }^{2}$ Don State Technical University, 1, Gagarin sq., 344003, Rostov on Don, Russia
}

\begin{abstract}
The article presents the results of a study of the structure of social and psychological attitudes of students studying in the technical higher educational institution. By means of correlation analysis the interrelations have been established between social and psychological attitudes within the every stage of studying. It has been found that the structure of social and psychological attitudes occurs as a holistic pattern among both 2 nd course students and 4 th course students. Due to that energy redistribution occurs from the strongly pronounced units to the suppressed ones. Moreover, it has been found that there is no contradistinction of altruism and egoism among 2 nd course students being indicative of a certain personal infantilism of the focus group respondents. In contrast, the given dichotomy has been already generated by 4th course students.
\end{abstract}

\section{Introduction}

Social and psychological attitudes are one of the most important characteristics that determine the "social value" of the individual. An attitude in psychology is defined as an unconscious state of readiness, predisposition to activity, which can be used to satisfy a particular need [1]. According to Berry et al. [2], "the attitude is a complete dynamic state of the subject, a state of readiness for a certain activity, a state that is determined by two factors: the need of the subject and the corresponding objective situation".

In social psychology, an attitude is considered as a predisposition to evaluate and determine a certain way of behavior based on needs and specific conditions of activity. The main meaning of training is not only and not so much in the assimilation of knowledge, but in the formation of a future specialist's complete structure of personal qualities.

In modern conditions, it is particularly important to obtain objective information about whether the chosen profession corresponds to the personal interests and inclinations of the student and how the personal and professional development of the future specialist are carried out. Therefore, even at the stage of higher education, it is necessary to identify such structural changes in the personality and, accordingly, to study the formation of such personal neoplasms that determine the professional and personal formation of the future

* Corresponding author: spopov1957@yandex.ru 
specialist. In this regard, studies of students' social and psychological attitudes as a component of the structure of their professional consciousness are of particular importance.

The method of diagnostics of social and psychological attitudes of the person was proposed by the doctor of psychological Sciences Potemkina [3]. The essence of this technique is that it allows you to diagnose the degree of severity and interrelation of social and psychological attitudes not only in an individual, but also in a group of people. In general, this method is an example of a subjective psychological test and is a multi-factor questionnaire consisting of two parts, the processing of which leads to the results of eight dependent variables measured on a metric scale, which, as is known, provides researchers with the widest possible set of data processing methods.

A thorough study of the literature allows us to offer the following list of recent research papers devoted to the study of social and psychological attitudes of the student population.

So, Cunningham et al. [4] using this tool, established the priority orientations for medical University students. Falk et al. [5] (students of the technical University) and Fishbein et al. [6] (students of the medical school) studied the relationship between social and psychological attitudes and the year of study. Erdogan [7] (University students and vocational school students) carried out a comparative analysis of the two categories of students and simultaneously identified the relationship between social and psychological attitudes and value orientations. Haas [8] (students of the Institute of engineering technologies and natural Sciences) studied the relationship between social and psychological attitudes and the orientation of the students' personality. Wilcox [9] (students of the technical University) established the relationship between social and psychological attitudes and the direction of the student's training. Friese et al. [10] (students of medical and pedagogical universities) conducted a comparative analysis of the features of professional self-determination of future specialists of helping professions. Richardson et al. [11] (full-time and part-time students of the University's faculty of law) performed a comparative analysis of the two categories of students and simultaneously identified relationships between social and psychological attitudes and students' ideas about their professional careers. Robinson et al. [12] (cadets of the military Institute) established the relationship between the social and psychological attitudes of students and their subjective well-being. Liu M. et al. [13] (University students) identified relationships between social and pedagogical attitudes and students' perceptions of themselves as subordinate individuals. And finally, Strack et al. [14] (students of the medical Academy) identified relationships between the social and psychological attitudes of students, their professional burnout and the qualities of the dark triad.

From the given list it follows that at present the features of social and psychological attitudes of students of technical universities can be attributed to a little-studied area of psychological knowledge.

Based on this circumstance, the purpose of this investigation was to study the structure of social and psychological attitudes of students of technical universities at various stages of studying. Research problem:

1. Identification of social and psychological attitudes of students studying in the second and the fourth years of the University.

2. Determination of indicators of the severity of social and psychological attitudes among students of these courses.

3. Establishing relationships between social and psychological attitudes within each focus group. 


\section{Materials and Methods}

The study, which was carried out in September-October 2018, was attended by 43 students of the faculty of Transport, service and maintenance of the Don State Technical University, Rostov on Don. The age of the subjects ranged from 18 to 24 years.

The gender composition was as follows: girls $-6.98 \%$, boys $-93.02 \%$.

The distribution of subjects by years of study (courses) was as follows: 2 nd year - 28 people; 4th year - 15 people.

As a research tool, we used the method of O.F. Potemkina "Diagnostics of social and psychological attitudes of the individual in the motivational and need sphere", aimed at identifying the degree of expression of social and psychological attitudes to "altruism egoism", "process - result", "freedom - power", "work - money" [3]. For each of these attitudes, the respondent can score from 1 to 10 points.

\section{Results and Discussion}

The indicators of the severity of social and psychological attitudes of the University students obtained after processing the questionnaires are presented in the table 1 .

Table 1. Indicators of the severity of social and psychological attitudes among students of the 2nd and 4 th courses of the University (in average points).

\begin{tabular}{|c|l|c|c|}
\hline No & Social and psychological attitude & 2nd course & 4th course \\
\hline 1 & Process & $5.57 \pm 1.91$ & $5.87 \pm 1.64$ \\
\hline 2 & Result & $6.29 \pm 1.63$ & $5.53 \pm 1.51$ \\
\hline 3 & Altruism & $4.86 \pm 2.10$ & $5.97 \pm 2.19$ \\
\hline 4 & Egoism & $4.75 \pm 2.19$ & $5.27 \pm 2.02$ \\
\hline 5 & Work & $6.07 \pm 1.96$ & $5.37 \pm 2.27$ \\
\hline 6 & Freedom & $6.25 \pm 1.48$ & $7.23 \pm 1.78$ \\
\hline 7 & Power & $3.96 \pm 2.25$ & $4.57 \pm 2.04$ \\
\hline 8 & Money & $3.80 \pm 2.30$ & $4.80 \pm 1.94$ \\
\hline
\end{tabular}

The least pronounced (or, as they say, frustrated) in second-year students are "power orientation" and "money orientation". The trend of average values suggests that by the second year of the University students, both of these attitudes are expressed to a very small extent.

In the moving to a focus group of students of the fourth year, we find (see table 1) that the most pronounced are "orientation to freedom", "orientation to altruism" and "orientation to process". It is known that altruism is the most valuable social motivation that distinguishes a mature person [15]. The attitude to process indicates that the work or other activity is interesting for the student. At the same time, the quality of the student's reliability may suffer: there may be delays in the delivery of works by the deadline, and productivity may decrease. The altruistic attitude indicates the student's need to help others, sometimes even to the detriment of himself. And the attitude to freedom indicates the student's desire for independence - in planning work, in making decisions, in building interpersonal relationships.

The "power orientation" and "money orientation" are the least pronounced in fourthyear students, as well as in sophomores, but the severity of these attitudes increases by the fourth year. 
In addition, as follows from the table 1, by the fourth year, the intensity of "process orientation", "altruistic orientation", "egoistic orientation", and "freedom orientation" increases. On the contrary, the intensity of "result orientation" and "work orientation" decreases.

The next stage of our work was to establish relationships between social and psychological attitudes within each focus group. To do this, a correlation analysis of the results of an empirical study was performed using the SPSS 13 for Windows program. The correlation analysis data is presented in tables 2 and 3 (only significant correlations are placed).

As a mathematical equivalent of the relationships between social and psychological attitudes, we used indicators of significant correlation between the numerical values of the severity of attitudes. In all cases, we calculated the Pearson correlation coefficient. Correlation ensembles that reflect the results obtained are shown in Fig. 1 and 2.

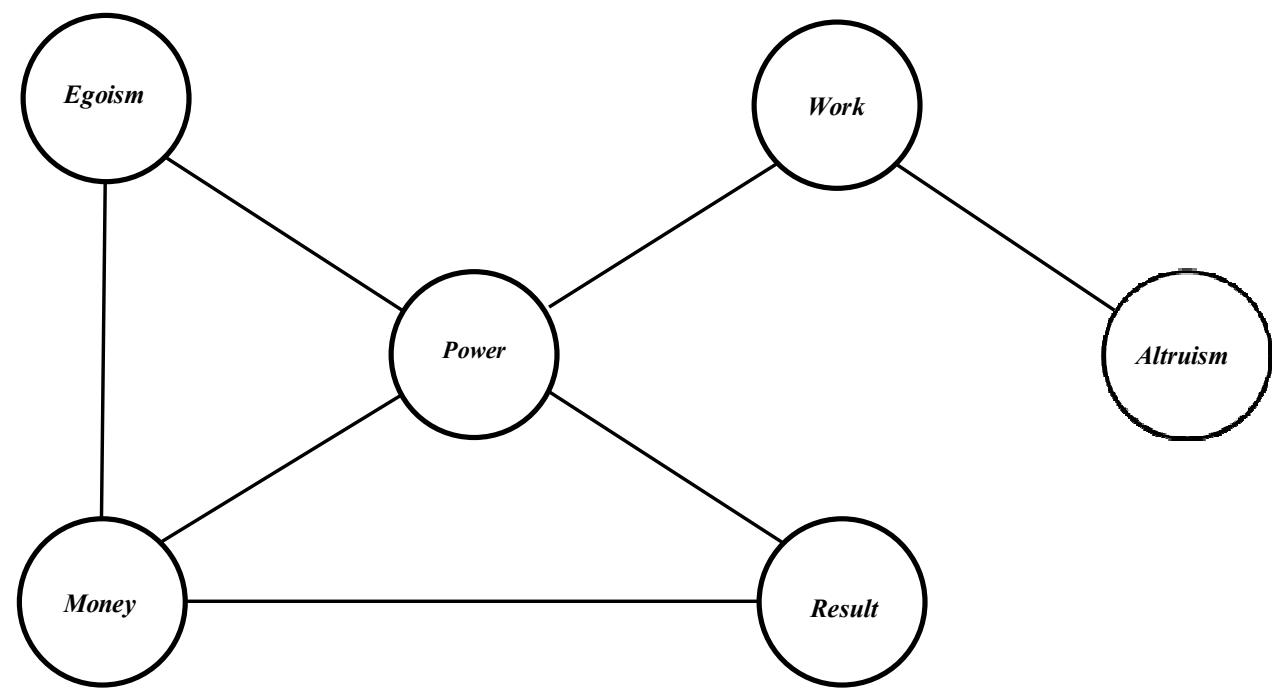

Fig. 1. Scheme of interrelations of social and psychological attitudes of second-year students (All correlations are the direct ones).

From the data presented in Fig. 1, it should be noted that in the focus group of secondyear students, there are the following groups of attitudes: "orientation to power orientation to egoism - orientation to money - orientation to result" and "orientation to power - orientation to work - orientation to altruism".

It should be noted that the two mentioned substructures include both the most pronounced orientations ("result orientation", "work orientation") and the orientations that are most frustrated ("money orientation", "power orientation"). In this case, the structure of the correlation ensemble does not have a gap, i.e. it is a single whole. This suggests that in the structure of social and psychological attitudes of second-year students, there is a redistribution of mental energy due to the coexistence of pronounced and frustrated attitudes; at the same time, the energy of the first helps to overcome the difficulties that arise in the second.

It is also necessary to note the unformed moral dichotomy "altruism-egoism" in secondyear students, which is evidence of their relative personal immaturity and a strong enough orientation to meet their own selfish needs. 
Table 2. Correlations between social and psychological attitudes for the 2 nd year focus group.

\begin{tabular}{|c|c|c|c|c|c|c|c|c|c|c|}
\hline \multirow{2}{*}{$\begin{array}{l}\mathbf{N} \\
\mathbf{0}\end{array}$} & \multirow{2}{*}{\multicolumn{2}{|c|}{ Variable }} & \multicolumn{8}{|c|}{ Social and psychological attitude } \\
\hline & & & \multirow{2}{*}{$\begin{array}{c}\text { Proce } \\
\text { ss }\end{array}$} & \multirow{2}{*}{$\begin{array}{c}\text { Resul } \\
t\end{array}$} & \multirow{2}{*}{$\begin{array}{c}\text { Altru } \\
\text { ism }\end{array}$} & \multirow{2}{*}{$\begin{array}{c}\text { Egois } \\
\mathbf{m}\end{array}$} & \multirow{2}{*}{ Work } & \multirow{2}{*}{$\begin{array}{c}\text { Freed } \\
\text { om }\end{array}$} & \multirow{2}{*}{$\begin{array}{c}\text { Powe } \\
\text { r }\end{array}$} & \multirow{2}{*}{$\begin{array}{c}\text { Mone } \\
\text { y }\end{array}$} \\
\hline \multirow{3}{*}{1} & \multirow{3}{*}{$\begin{array}{l}\text { Proce } \\
\text { ss }\end{array}$} & $\begin{array}{l}\text { Pearson } \\
\text { Correlation }\end{array}$ & & & & & & & & \\
\hline & & $\begin{array}{l}\text { Sig. (2- } \\
\text { tailed) }\end{array}$ & & & & & & & & \\
\hline & & $\mathrm{N}$ & & & & & & & & \\
\hline \multirow{3}{*}{2} & \multirow{3}{*}{$\begin{array}{l}\text { Resu } \\
\text { lt }\end{array}$} & $\begin{array}{l}\text { Pearson } \\
\text { Correlation }\end{array}$ & & & & & & & $\begin{array}{c}0.487 \\
* *\end{array}$ & $\begin{array}{c}0.506 \\
* *\end{array}$ \\
\hline & & $\begin{array}{l}\text { Sig. (2- } \\
\text { tailed) }\end{array}$ & & & & & & & 0.009 & 0.006 \\
\hline & & $\mathrm{N}$ & & & & & & & 28 & 28 \\
\hline \multirow{3}{*}{3} & \multirow{3}{*}{$\begin{array}{l}\text { Altru } \\
\text { ism }\end{array}$} & $\begin{array}{l}\text { Pearson } \\
\text { Correlation }\end{array}$ & & & & & $\begin{array}{c}0.559 \\
* *\end{array}$ & & & \\
\hline & & $\begin{array}{l}\text { Sig. (2- } \\
\text { tailed) }\end{array}$ & & & & & 0.002 & & & \\
\hline & & $\mathrm{N}$ & & & & & 28 & & & \\
\hline \multirow{3}{*}{4} & \multirow{3}{*}{$\begin{array}{l}\text { Egoi } \\
\text { sm }\end{array}$} & $\begin{array}{l}\text { Pearson } \\
\text { Correlation }\end{array}$ & & & & & & & $\begin{array}{c}0.374 \\
*\end{array}$ & $\begin{array}{c}0.558 \\
* *\end{array}$ \\
\hline & & $\begin{array}{l}\text { Sig. (2- } \\
\text { tailed) }\end{array}$ & & & & & & & 0.050 & 0.002 \\
\hline & & $\mathrm{N}$ & & & & & & & 28 & 28 \\
\hline \multirow{3}{*}{5} & \multirow{3}{*}{ Work } & $\begin{array}{l}\text { Pearson } \\
\text { Correlation }\end{array}$ & & & $\begin{array}{c}0.559 \\
* *\end{array}$ & & & & $\begin{array}{c}0.453 \\
*\end{array}$ & \\
\hline & & $\begin{array}{l}\text { Sig. (2- } \\
\text { tailed) }\end{array}$ & & & 0.002 & & & & 0.015 & \\
\hline & & $\mathrm{N}$ & & & 28 & & & & 28 & \\
\hline \multirow{3}{*}{6} & \multirow{3}{*}{$\begin{array}{l}\text { Freed } \\
\text { om }\end{array}$} & $\begin{array}{l}\text { Pearson } \\
\text { Correlation }\end{array}$ & & & & & & & & \\
\hline & & $\begin{array}{l}\text { Sig. (2- } \\
\text { tailed) }\end{array}$ & & & & & & & & \\
\hline & & $\mathrm{N}$ & & & & & & & & \\
\hline \multirow{3}{*}{7} & \multirow{3}{*}{$\begin{array}{l}\text { Powe } \\
\mathrm{r}\end{array}$} & $\begin{array}{l}\text { Pearson } \\
\text { Correlation }\end{array}$ & & $\begin{array}{c}0.487 \\
* *\end{array}$ & & $\begin{array}{c}0.374 \\
*\end{array}$ & $\begin{array}{c}0.453 \\
*\end{array}$ & & & $\begin{array}{c}0.396 \\
*\end{array}$ \\
\hline & & $\begin{array}{l}\text { Sig. (2- } \\
\text { tailed) }\end{array}$ & & 0.009 & & 0.050 & 0.015 & & & 0.037 \\
\hline & & $\mathrm{N}$ & & 28 & & 28 & 28 & & & 28 \\
\hline \multirow{3}{*}{8} & \multirow{3}{*}{$\begin{array}{l}\text { Mon } \\
\text { ey }\end{array}$} & $\begin{array}{l}\text { Pearson } \\
\text { Correlation }\end{array}$ & & $\begin{array}{c}0.506 \\
* *\end{array}$ & & $\begin{array}{c}0.558 \\
* *\end{array}$ & & & $\begin{array}{c}0.396 \\
*\end{array}$ & \\
\hline & & $\begin{array}{l}\text { Sig. (2- } \\
\text { tailed) }\end{array}$ & & 0.006 & & 0.002 & & & 0.037 & \\
\hline & & $\mathrm{N}$ & & 28 & & 28 & & & 28 & \\
\hline
\end{tabular}

Where: * - Correlation is significant at the 0.05 level (2-tailed), ** - Correlation is significant at the 0.01 level (2-tailed). 
Table 3. Correlations between social and psychological attitudes for the 4th year focus group.

\begin{tabular}{|c|c|c|c|c|c|c|c|c|c|c|}
\hline \multirow{5}{*}{$\begin{array}{l}\mathbf{N} \\
\mathbf{0}\end{array}$} & \multirow{2}{*}{\multicolumn{2}{|c|}{ Variable }} & \multicolumn{8}{|c|}{ Social and psychological attitude } \\
\hline & & & \multirow{2}{*}{$\begin{array}{c}\text { Proce } \\
\text { ss }\end{array}$} & \multirow{2}{*}{$\begin{array}{c}\text { Resu } \\
\text { It }\end{array}$} & \multirow{2}{*}{$\begin{array}{c}\text { Altruis } \\
\text { m }\end{array}$} & \multirow{2}{*}{$\begin{array}{c}\text { Egois } \\
\text { m }\end{array}$} & \multirow{2}{*}{$\begin{array}{c}\text { Wor } \\
\text { k }\end{array}$} & \multirow{2}{*}{$\begin{array}{c}\text { Freedo } \\
\text { m }\end{array}$} & \multirow{2}{*}{$\begin{array}{c}\text { Pow } \\
\text { er }\end{array}$} & \multirow{2}{*}{$\begin{array}{c}\text { Mone } \\
\mathbf{y}\end{array}$} \\
\hline & $\begin{array}{l}\text { Proc } \\
\text { ess }\end{array}$ & $\begin{array}{l}\text { Pearson } \\
\text { Correlati } \\
\text { on }\end{array}$ & & & & & & & & \\
\hline & & $\begin{array}{l}\text { Sig. (2- } \\
\text { tailed) }\end{array}$ & & & & & & & & \\
\hline & & $\mathrm{N}$ & & & & & & & & \\
\hline \multirow[t]{3}{*}{2} & \multirow[t]{3}{*}{$\begin{array}{l}\text { Res } \\
\text { ult }\end{array}$} & $\begin{array}{l}\text { Pearson } \\
\text { Correlati } \\
\text { on }\end{array}$ & & & & & & & & \\
\hline & & $\begin{array}{l}\text { Sig. (2- } \\
\text { tailed) }\end{array}$ & & & & & & & & \\
\hline & & $\mathrm{N}$ & & & & & & & & \\
\hline \multirow[t]{3}{*}{3} & \multirow[t]{3}{*}{$\begin{array}{l}\text { Altr } \\
\text { uis } \\
\text { m }\end{array}$} & $\begin{array}{l}\text { Pearson } \\
\text { Correlati } \\
\text { on }\end{array}$ & & & & $\begin{array}{c}- \\
0.604 \\
*\end{array}$ & & & & $\begin{array}{c}- \\
0.684 \\
* *\end{array}$ \\
\hline & & $\begin{array}{l}\text { Sig. (2- } \\
\text { tailed) }\end{array}$ & & & & 0.017 & & & & 0.005 \\
\hline & & $\mathrm{N}$ & & & & 15 & & & & 15 \\
\hline \multirow[t]{3}{*}{4} & \multirow[t]{3}{*}{$\begin{array}{l}\text { Ego } \\
\text { ism }\end{array}$} & $\begin{array}{l}\text { Pearson } \\
\text { Correlati } \\
\text { on }\end{array}$ & & & $-0.604 *$ & & & & $\begin{array}{c}0.54 \\
2^{*}\end{array}$ & $\begin{array}{c}0.601 \\
*\end{array}$ \\
\hline & & $\begin{array}{l}\text { Sig. (2- } \\
\text { tailed) }\end{array}$ & & & 0.017 & & & & $\begin{array}{c}0.03 \\
7\end{array}$ & 0.018 \\
\hline & & $\mathrm{N}$ & & & 15 & & & & 15 & 15 \\
\hline \multirow[t]{3}{*}{5} & \multirow[t]{3}{*}{$\begin{array}{l}\text { Wor } \\
\mathrm{k}\end{array}$} & $\begin{array}{l}\text { Pearson } \\
\text { Correlati } \\
\text { on }\end{array}$ & & & & & & & & \\
\hline & & $\begin{array}{l}\text { Sig. (2- } \\
\text { tailed) }\end{array}$ & & & & & & & & \\
\hline & & $\mathrm{N}$ & & & & & & & & \\
\hline \multirow[t]{3}{*}{6} & \multirow[t]{3}{*}{$\begin{array}{l}\text { Free } \\
\text { dom }\end{array}$} & $\begin{array}{l}\text { Pearson } \\
\text { Correlati } \\
\text { on }\end{array}$ & & & & & & & & \\
\hline & & $\begin{array}{l}\text { Sig. (2- } \\
\text { tailed) }\end{array}$ & & & & & & & & \\
\hline & & $\mathrm{N}$ & & & & & & & & \\
\hline \multirow[t]{3}{*}{7} & \multirow[t]{3}{*}{$\begin{array}{l}\text { Pow } \\
\text { er }\end{array}$} & $\begin{array}{l}\text { Pearson } \\
\text { Correlati } \\
\text { on }\end{array}$ & & & & $\begin{array}{l}0.542 \\
*\end{array}$ & & & & \\
\hline & & $\begin{array}{l}\text { Sig. (2- } \\
\text { tailed) }\end{array}$ & & & & 0.037 & & & & \\
\hline & & $\mathrm{N}$ & & & & 15 & & & & \\
\hline 8 & $\begin{array}{l}\text { Mo } \\
\text { ney }\end{array}$ & $\begin{array}{l}\text { Pearson } \\
\text { Correlati }\end{array}$ & & & $\frac{-}{0.684 *}$ & $\begin{array}{c}0.601 \\
*\end{array}$ & & & & \\
\hline
\end{tabular}




\begin{tabular}{|l|l|l|l|c|c|c|l|l|l|}
\hline & on & & & $*$ & & & & & \\
\cline { 2 - 9 } & $\begin{array}{l}\text { Sig. (2- } \\
\text { tailed) }\end{array}$ & & & 0.005 & 0.018 & & & & \\
\cline { 2 - 9 } & $\mathrm{N}$ & & & 15 & 15 & & & & \\
\hline
\end{tabular}

Where: $*$ - Correlation is significant at the 0.05 level (2-tailed), ${ }^{* *}$ - Correlation is significant at the 0.01 level (2-tailed).

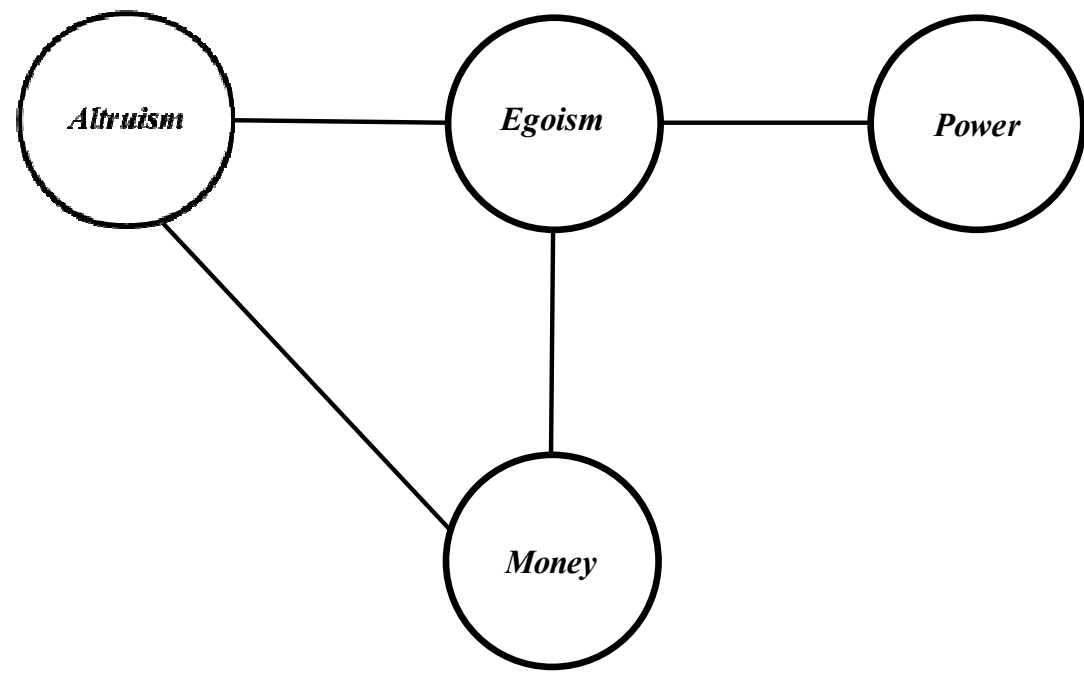

Fig. 2. Scheme of interrelations of social and psychological attitudes of fourth-year students (Correlation of "egoism" - "power" and "egoism" - "money" are the direct ones. The correlations "altruism" - "egoism" and "altruism" - "money" are the inverse ones).

On the contrary, from the data presented in Fig. 2, it follows that in the focus group of fourth-year students there is only one grouping of attitudes: "orientation to egoism orientation to altruism - orientation to money - orientation to power".

As in the previous case, this correlation ensemble includes both the most pronounced orientations ("orientation to altruism", "orientation to egoism") and the orientations that are most frustrated ("orientation to money", "orientation to power"). In this case, the structure of the correlation ensemble again does not have a gap, i.e. it is a single whole. This allows the structure to redistribute mental energy between different social and psychological attitudes and help maintain them all at a higher level than that of second-year students.

It should also be noted that fourth-year students are becoming aware of their powers, becoming subjectivity, and separating from a significant adult. This leads to a clear contrast between "altruism orientation" and "egoism orientation", which is expressed in a noticeable inverse correlation between these attitudes (see table 3). Thus, the dichotomy "altruism egoism" is grown, which forms the moral axis of the students' personality.

\section{Conclusions}

1. Using the method of diagnostics of social and psychological attitudes of the individual in the motivational and need sphere, the social and psychological attitudes of students studying in the second and fourth years of the University were identified.

2. Using the correlation analysis method, the relationships between social and psychological attitudes within each focus group were established. 
3. It was found that both 2nd-year students and 4th-year students have a holistic structure of social and psychological attitudes, due to which energy is redistributed from the most pronounced spheres to the frustrated ones.

4. It was found that the 2nd year students do not have the opposition of "altruism" and "egoism", which indicates a certain personal immaturity of the respondents of this focus group. On the contrary, this dichotomy has already been formed for 4th year students.

\section{References}

1. A.Adler, W. Beran Wolfe, The Pattern of Life (2015)

2. J.W. Berry, C. Sabatier, International journal of intercultural relations 35, 658-669 (2011)

3. M. Gagné, The Oxford Handbook of Work Engagement, Motivation, and Self Determination Theory (2014)

4. W.A. Cunningham, I. Johnson Haas, A. Jahn, The Oxford Handbook of Social Neuroscience (2011)

5. E.B. Falk, M. Dylan Lieberman, The Neural Bases of Human Belief Systems (2013)

6. M. Fishbein, I. Ajzen, Predicting and Changing Behavior: The Reasoned Action Approach (2011)

7. I. Erdogan, World Journal of Social Sciences 1(5), 82-97 (2011)

8. I. Johnson Haas, Neuroimaging Personality, Social Cognition, and Character (2016)

9. R.R. Wilcox, Introduction to robust estimation and hypothesis testing (2012)

10. M. Friese, C. Tucker Smith, M. Koever, M. Bluemke, Social and Personality Psychology Compass 10(4), 188-201 (2016).

11. M. Richardson, C. Abraham, R. Bond, Psychological bulletin 138(2), 353-387 (2012)

12. O.C. Robinson, F.G. Lopez, K. Ramos, S. Nartova-Bochaver, Journal of CrossCultural Psychology 44(5), $719-737$ (2013)

13. M. Liu, Y. Wang, Computers in Human Behavior 48, 212-218 (2015)

14. F. Strack, R. Deutsch, APA Handbook of Personality and Social Psychology (2015)

15. L.E. Park, J. Daniel Troisi, J.K. Maner, Journal of social and personal relationships 28(3), 315-335 (2011) 